\title{
Isolation and Identification of Low Molecular Weight Peptides in Gouda Cheese
}

\author{
Keiji IGOSHI, Naoki JIROMARU, \\ Hiromasa KOBAYASHI \\ and Shunrokuro ARIMA \\ Faculty of Agriculture, Kyushu Tokai University, \\ Choyo-son, Kumamoto-ken 869-14
}

(Received October 21, 1996)

\begin{abstract}
Ethanol soluble extracts in Gouda cheese (cheese before ripening and cheese ripened for 1 and 4 months) were prepared to examine low molecular weight peptides in the cheese. The extracts were fractionated by high pressure liquid chromatography (HPLC) fitted with ODS column and UV detection. As the ripening period progressed, the number and quantity of peptide peaks extracted increased. The amino acid sequence of the main peaks isolated from cheese ripened for 4 months were determined as follows ; Tyr, Phe, Trp, as 1-CN (f 17), (f 1-9), (f 1-13), (f 1-14), (f 1-16), (f 1-17) and $\beta-\mathrm{CN}$ (f 47-52). With the exception of $\beta-\mathrm{CN}$ (f 47-52) and amino acid; these peptides were fragments contained in $\alpha \mathrm{S} 1-\mathrm{CN}(\mathrm{f} 1-23)$ produced specifically by the action of chymosin. Therefore, it was considered that these $\mathrm{N}$-terminal peptides of $\alpha$ s1$\mathrm{CN}$ identified in the cheese, were produced from $23 \mathrm{~N}$-terminal residues of $\alpha \mathrm{s} 1-\mathrm{CN}$ on the action of proteolytic enzyme from Lactic acid bacteria which existed in the cheese.
\end{abstract}

Anim. Sci. Technol. (Jpn.) 68 (4) : 385-388, 1997

Key words : Cheese peptide, Gouda cheese, Ripening, $\alpha$ s1-CN(f 1-23), HPLC

Cheese ripening is a complex process that involves three activities: glycolysis, lipolysis, and proteolysis. Of these three, proteolysis is the most important process because it is relat ed to the development of texture and flavor during cheese ripening ${ }^{5.6)}$. Such compounds as peptides and amino acids, resulting from the proteolysis, are important constituents that affect the cheese quality. It is important to isolate and identify individual peptides generated during ripening to completely understand proteolysis in cheese. There are studies $^{1,6)}$ on the proteolysis in cheese. How- ever no detailed knowledge of products, especially low molecular weight (LMW) peptide, has been reported.

During the last decade, due to the good resolution of complex mixtures, reversed-phase high pressure liquid chromatography ( $R P$ HPLC) has been widely employed in food analysis. RP-HPLC analysis can be used advantageously for cheese quality, ripening characteristics, process development such as accelerated cheese, and separation of peptides from cheese.

In this paper, LMW peptides were isolated

ゴーダチーズからの低分子ペプチドの分離とその一次構造 : 并越敬司・治郎丸直樹・小林弘昌・有馬俊六郎 (九州 東海大学祳学部, 熊本県長陽村 869-14) 


\section{IGOSHI, JIROMARU, KOBAYASHI and ARIMA}

and purified in Gouda cheese fractionated by HPLC, and amino acids composition were idetified and $\mathrm{N}$-terminal amino acids sequence was made.

\section{Materials and Methods}

Gouda cheese ripened for 1 and 4 months and unripe cheese or 0 -month ripened cheese obtained from Snow Brand Milk Product Co, Ltd., were used.

Sample of Gouda cheese $(20 \mathrm{~g})$, which was taken below $1 \mathrm{~cm}$ of the cheese surface, was grated with $100 \mathrm{~m} l$ of distilled water and homogenized for $1 \mathrm{~min}$ with a Polytron PT 20 (Kinematica, Switzerland). The homogenate was then centrifuged for $30 \mathrm{~min}$ at $4,000 \mathrm{rpm}$ to remove the cream layer. After removing the cream layer, the precipitate and supernatant were mixed, and then the cheese slurry was adjusted to $\mathrm{pH} 4.5$ by the addition of $1 \mathrm{~N} \mathrm{HCl}$ and stirred for $15 \mathrm{~min}$. After insoluble materials were removed by centrifugation at 8,000 rpm, the $\mathrm{pH} 4.5$ soluble fraction, recovered through cotton, was combined with ethanol (Et $-\mathrm{OH})$ to a $70 \%(\mathrm{~V} / \mathrm{V})$ final concentration to eliminate the protein completely. The suspension was left to stand over $4 \mathrm{hr}$ and centrifuged again at $10,000 \mathrm{rpm}$ for $30 \mathrm{~min}$. The clear solution was then recovered. The $70 \% \mathrm{Et}-\mathrm{OH}$ soluble peptides were used for HPLC analysis. All the treatments described were carried out at $4^{\circ} \mathrm{C}$.

A HPLC fitted with a YMC ODS column (150 $\times 4.6 \mathrm{~mm})$ and a UV detection at a wavelength of $220 \mathrm{~nm}$ was used for the separation of peptides. The $70 \%$ Et-OH soluble fraction obtained above was dried in an evaporator, dissolved in $0.1 \%$ trifluoroacetic acid and injected into a pump (LC-6 A, Shimazu Corp., Kyoto, Japan) using an automatic injector (SCL $6 \mathrm{~B}$, Shimazu Corp., Kyoto, Japan). The injected sample was eluted with $0.1 \%$ trifluoroacetic acid-acetonitrile in the mobile phase at a flow rate of $0.8 \mathrm{ml} / \mathrm{min}$. The concentration of the mobile phase modifier (acetonitrile) increased linearly from 0 to $50 \%$ over $125 \mathrm{~min}(0.4 \% / \mathrm{min})$. The main peaks that were present in 0 -month and 4 -month ripened cheese were isolated and purified by repeating the procedure 2 or 3 times with HPLC under the same conditions. When one peak was divided into 2 or 3 peaks by rechromatography of HPLC, the main peak was adopted as the peak for determination of the sequence. Purified peptides were evaporated, sealed under vacuum and hydrolyzed at $130^{\circ} \mathrm{C}$ for $3 \mathrm{hr}$ with constant-boiling $\mathrm{HCl}$. The amino acid composition of hydrolysate was analyzed with an automatic amino acid analyzer (Hitachi Model 835). Three amino acid sequences of each peptide were furthermore determined by an automatic protein sequencer (PSQ-1, Shimazu Corp., Kyoto, Japan).

\section{Results and Discussion}

LMW peptides of unripe cheese and cheese ripened for 1 and 4 months were extracted and fractionated by HPLC. Fig. 1 shows the HPLC patterns for the cheese extracts from three different ripening periods. The patterns correlated with their ripening period, i.e., as the ripening period increased, the number and quantity of peptide peaks extracted increased. Therefore, the HPLC profiles of the extracts could provide valuable information on the ripening time of the cheese and is useful in monitoring the degree of cheese ripening.

Some of the peptides were isolated from unripe cheese and 4-month ripened cheese. The amino acid composition and $\mathrm{N}$-terminal amino acid sequence of each peptide were examined, and the amino acid sequence of the purified peptides was determined.

The amino acid sequence of ten peaks was determined only in cheese ripened for 4 months. All peaks were identified as peptides, except for peaks 1,2 and 5 which were amino acid corresponding to Tyr, Phe and Trp, respectively. Peaks $3,4,6,7,8,9$ and 10 were identified as $\alpha$ s $1-\mathrm{CN}(\mathrm{f} 1-9), \quad \alpha \mathrm{s} 1-\mathrm{CN}(\mathrm{f} 1-7)$, 


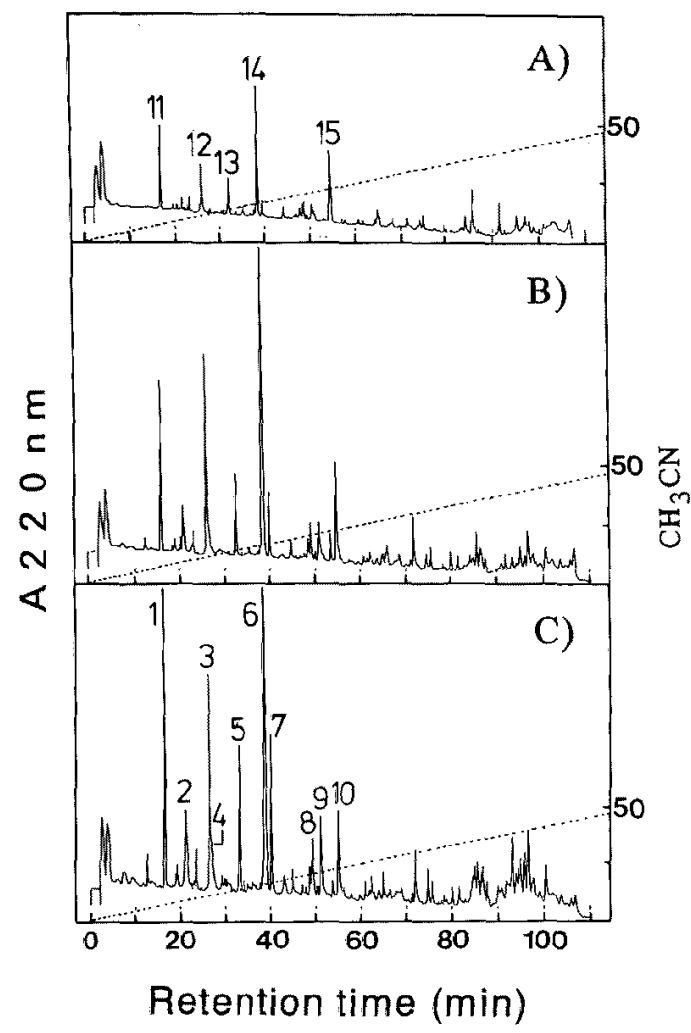

Fig. 1. HPLC profiles of $70 \%$ ethanol soluble extracts from the Gouda cheese.

A) : unripe cheese, B) : 1-month ripened cheese, C) : 4-month ripened cheese, Dotted line: gradient profile of acetonitrile, Elution conditions were described in the text.

$\alpha \mathrm{s} 1-\mathrm{CN}$ (f 1-13), $\alpha$ s $1-\mathrm{CN}$ (f 1 14), $\beta-\mathrm{CN}$ (f 47-52), $\alpha$ s 1-CN (f 1-16), and $\alpha$ s 1-CN (f 1-17), respectively. Although some peaks of undetermined peptides were also purified with HPLC, their amino acid sequence could not be determined. It was especially difficult to purify the peaks between $80 \mathrm{~min}$ and $100 \mathrm{~min}$ of retention time with the described method for purification in this experiment. Peptides and amino acids which were identified from 4-month ripened cheese were also found in unripe cheese, except for $\alpha$ s 1-CN (f 1-7). Peaks 11 (Tyr), 12 ( $\alpha$ s 1-CN (f 1-9)), 13 (Trp), $14(\alpha \mathrm{s} 1-\mathrm{CN}$ (f 1-13)) and $15(\alpha \mathrm{s} 1$ CN (f 1-16)) were considered the main peaks in unripe cheese. The peaks found in unripe cheese increased in size with the lengthening of ripening period. However the peak corresponding to $\alpha$ s 1-CN (f $1-16$ ) hardly increased.

Kaminogawa et al. ${ }^{1)}$ identified $\alpha$ s 1-CN (f 1-9), $\alpha \mathrm{S} 1-\mathrm{CN}(\mathrm{f} 1-13), \quad \alpha \mathrm{S} 1-\mathrm{CN}(1-14)$ in the same Gouda-type cheese. We could, in addition to these peptides, isolate amino acids and peptides such as as 1-CN (f 1-7), $\alpha$ s 1-CN (f 1-16), $\alpha \mathrm{s} 1-\mathrm{CN}(\mathrm{f} 1-17)$, and $\beta-\mathrm{CN}(\mathrm{f} 47-52)$. Furthermore, the HPLC profiles obtained followed a clear pattern. It was considered that the use of ethanol might be suitable for extracting LMW peptides from cheese.

Recently, five peptides ( $\alpha$ s1-CN (f 1-9, f 1-13, $\mathrm{f} 11$ ?, $\mathrm{f} 1-$ ? and $\mathrm{f} 1-$ ?) $)^{2)}$ were found in Cheddar cheese. These peptides have been considered to be produced by the action of the lactococcal cell wall proteinase on the peptide $\alpha$ s $1-\mathrm{CN}$ (f 1 $23)^{3)}$ which is rapidly produced by chymosin ${ }^{2)}$. The (f 1-9), (f 1-13) and (f 1-14) fragments of $\alpha$ s 1 $-\mathrm{CN}$, which were identified in Gouda-type cheese, together with its (f $1-7)$, (f $1-18)$, (f $1-20)$, and (f 14-23) fragments, were isolated from a digest of $\alpha \mathrm{s} 1-\mathrm{CN}$ (f 1-23) made with a cell free extract from Lactococcus lactis subsp. lactis $\mathrm{H}$ 61. Furthermore, two proteases, designated as LEP-I and II, from the strain, were purified and characterized as enzymes related to the formation of these peptides ${ }^{7,8)}$. In the experiment, all peptides icentified except for $\beta-\mathrm{CN}$ (f 47-52) were from the $\mathrm{N}$-terminal region of $\alpha \mathrm{s} 1-\mathrm{CN}$. That is, these peptides belonged to $\alpha \mathrm{S} 1-\mathrm{CN}$ (f 1 -23) which was produced by cleavage of the Phe 23-Mct 24 bond of $\alpha s 1-\mathrm{CN}$ by chymosin during the initial stage of cheese making ${ }^{3)}$. It was, therefore, suggested that $\mathrm{N}$-terminal peptides $\alpha$ s $1-\mathrm{CN}$ (f 1-7), (f 1-9), (f 1-13), (f 1-14), (f $1-$ 16) and (f 1-17) of $\alpha$ s 1-CN in the Gouda cheese in this experiment were also produced from $\alpha \mathrm{s}$ $1-\mathrm{CN}$ (f 1-23), which was formed by chymosin ${ }^{3)}$, by the action of protease from Lactococcal strain of starter bacteria in cheese. Hydrolysis of $\alpha$ s 1-CN (f 1-23) might be the important proteolysis for the formation and degradation of LMW peptides during cheese ripening. 


\section{References}

1) Fox PF. Proteolysis during cheese manufacture and ripening. J. Dairy Sci., $72: 1379-1400$. 1989.

2) Fox PF, Singh TK. McSweeney PLH. Proteolysis in cheese during ripening. In : Biochemistry of milk products. (Andrews AT, Varley J eds.) 1-31. The Royal Society of Chemistry. Cambridge. 1994.

3) Grappin R, Rank TC, Olson NF. Primary proteolysis of cheese proteins during ripening. J. Dairy Sci., 68: 531-540. 1985.

4) Kaminogawa $S$, Yan TR, Azuma N, Yamauchi K. Identification of low molecular weight peptides in Gouda-type cheese and evidence for the formation if these peptides from $23 \mathrm{~N}$ terminal residues of $\alpha s 1-\mathrm{CN}$ (f $1-23$ ) by pro- teinases of streptococcus cremoris $\mathrm{H} 61$. J. food Sci., 51 : 1253-1264. 1986.

5) Lawrence RC, Creamer LK, Gilles J. Texture development during cheese ripening. J. Dairy Sci., $70: 1748-1760.1987$.

6) Visser S. Proteolysis enzymes and their relation to cheese ripening and flavor: An overview. J. Dairy Sci., 76 : 329-350. 1993.

7) Yan TR, Azuma N, Kaminogawa S, Yamauchi K. Purification and characterization of substrate-size-recognizing metalloendopeptidase from Streptococcus cremoris H61. Appl. Environ. Microbiol., 53 : 2296-2302. 1987.

8) Yan TR, Azuma N, Kaminogawa $S, Y$ amauchi K. Purification and characterization of a novel metalloendopeptidase from Streptococcus cremoris H61. Eur. J. Biochem., 163 : 259-265. 1987. 